\title{
MIDRASH AS EXEGETICAL APPROACH OF EARLY JEWISH EXEGESIS, WITH SOME EXAMPLES FROM THE BOOK OF RUTH
}

\author{
Authors: \\ Man Ki Chan ${ }^{1}$
}

Pieter M. Venter

\section{Affiliations: \\ ${ }^{1}$ Department of Old \\ Testament Studies, \\ University of Pretoria, \\ South Africa}

\section{Correspondence to: \\ Pieter Venter}

email:

pm.venter@up.ac.za

\section{Postal address:}

PO Box 914-1530, Wingate

Park 0153, South Africa

\section{Keywords:}

The Book of Ruth; interpretation; Jewish exegesis; Midrash social relevancy; reader community

\section{Dates:}

Received: 20 Jan. 2010

Accepted: 21 June 2010

Published: 18 Oct. 2010

How to cite this article:

Chan, M-K. \& Venter, P.M., 2010, 'Midrash as exegetical approach of early Jewish exegesis, with some examples from the Book of Ruth', HTS Teologiese Studies/ Theological Studies 66(1), Art. \# 787, 6 pages. DOI 10.4102/hts.v66i1.787

\section{This article is available}

http://www.hts.org.za

\section{Note:}

This article is a reworked version of a section of the $\mathrm{PhD}$ dissertation 'A comparative study between Jewish commentary and patristic literature on the Book of Ruth', completed under supervision of Prof. Dr Pieter M. Venter Department of Old Testament Studies, Faculty of Theology, University of Pretoria, 2009.

\section{(c) 2010. The Authors.} Licensee: OpenJournals Publishing. This work is licensed under the Creative Commons Attribution License.

\section{ABSTRACT}

This article deals with the exegetical approach of the early Jewish school. It discusses the meaning and definition of midrash as a distinctive approach in Jewish interpretation. The relationship between midrash and exegesis is also examined. It is shown how the process of interpretation is affected by the use of midrash principles. It is also pointed out that the ancient interpretative method of midrash had social relevancy. The midrashic interpreters maintained the interest of the community and fulfilled the needs of their generation. The conclusion is drawn that early Jewish exegetes did not explain the text for its inherent meaning, but rather for its use in personal purposes. They tended to read some agendas and issues into the text from the exegetes themselves and their surrounding backgrounds. They aimed to meet the requirement of the social and political expectations of their reader community. Interpretation was used as a tool for this purpose. This exegetical trend is finally illustrated with some examples of interpretation of the Book of Ruth.

\section{INTRODUCTION}

Midrash was an exegetical approach used in early Jewish religion. Scholars have indicated that there are some shared interpretative traditions between Qumranic Bible exegesis and Jewish exegesis (cf. Talmon 2002:5). Moreover, Steven D. Fraade's (1991) research led to a scholarly approach, called 'comparative midrash'. In terms of such an approach, 'midrash' denotes scriptural interpretation in general, whether explicit or inferred. The approach found in the newer books of the Bible, was also used in the times before the canon was finalised. The approach can be seen in reworked sections of already existing earlier scriptural books or passages (cf. Fraade 1991:102). In this article, we examine the meaning of midrash as a distinctive interpretative method, as well as its exegetical function and its purpose in early Jewish tradition. An interpretation of the Book of Ruth is used to illustrate the main purpose of the Jewish sages' use of midrash.

\section{THE MEANING AND DEFINITION OF MIDRASH}

\section{Meaning}

Regarding the meaning of midrash, Lieve M. Teugels (2004:38) indicates that midrash refers to the literary genre used in rabbinic commentaries on the Hebrew Bible. According to Teugels, 'midrash' means the same as 'rabbinic exegesis', if exegesis is taken in the broad sense of 'commentary on', or 'interpretation of', Scripture. Jewish commentaries or midrash do not only contain clarifications of difficulties on a linguistic or textual level, but also narrative expansions and elaborations of the scriptural text, which would not today be called exegesis. Therefore, the term 'midrash' will be used in the current article in preference to 'exegesis' for referring to the specific rabbinic way of interpreting the Hebrew Scripture. ${ }^{1}$

Among the different scholarly opinions on the meaning of midrash, Gary Porton's (1985:103-138) view is innovative, illuminating and comprehensive. He states that midrash carries three different technical meanings:

- it signifies biblical interpretation

- it designates the process of that interpretation and

- it describes the collections of such interpretations.

Our definition of midrash is closely linked with Porton's definition of midrash. The following will illustrate the meaning, characteristics, and exegetical principles of midrash.

\section{Defining midrash}

The purpose and function of midrash is understood to be some kind of exegesis, involving the explanation of a scriptural quotation (cf. Van der Heide 1997:45). It is very clear that rabbinic literature in general possesses an emphatic interpretative drive. The constant reference to the Scriptures is one of its most conspicuous features. Scholars still continue to search for the meaning of Scriptures. ${ }^{2}$ The Scriptures and their meanings are almost omnipresent, even in the absence of 'midrash-form'.

1.Van der Heide's (1997) view that midrash differs from modern exegesis is given credit, but I cannot agree with Van der Heide's presentation of midrash. Although Van der Heide (1997:46) states at the outset that the functions of midrash range from pure explication ... to blatant 'reading in', the examples of midrash that he gives, only stress the 'mere homiletic or rhetorical function' of midrash (1997:51). One example is described as 'pure midrashic embellishments of haggada', whereas another is regarded as 'rhetorically dressed up with text quotations' (Van der Heide 1997:52). In this way, Van der Heide plays down the hermeneutic function of midrash, even when it is present in the passages that he quotes. Such a one-sided presentation of midrash has in the past given rise to, and in the present continues to give rise to, misunderstandings of, and even contempt for, midrash. Such a presentation is rendered out of date by recent developments in midrash studies, such as Boyarin's theories on intertextuality.

2.Cf. Halivni's (1983) approach to the origin of midrash in his Midrash. Mishnah, and Gemara and in a different perspective, in his 1991 Peshat and Darash: Plain and applied meaning in rabbinic exegesis. Halivni (1991:62), in his chapter 'Between Scripture and its rewording' is convinced that 'rabbinic exegesis', in all its complexity, leads to the heart of rabbinic Judaism; he opens his article with the observation: 'Midrash is saying again of what Scripture says.' 


\section{In the Hebrew Bible}

Around the middle of the previous century, historical criticism of the Bible started to take notice of the phenomenon of midrash. Scholars with a historic interest traced the origins of midrash back to inner-biblical interpretation (cf. Teugels 2004:141).

Geza Vermes was a pioneer ${ }^{3}$ in linking the study of midrash with historical biblical criticism. In order to understand the nature and purpose of midrash, he stresses that it is necessary to glance at those biblical passages that foreshadow and prompt the discipline of exegesis. ${ }^{4}$ He takes the view that the rewriting and interpreting of older material in the exilic and post-exilic parts of the Old Testament is 'no doubt a midrashic process'. The continuity between Bible and midrash is so evident that, according to Vermes, 'post-biblical midrash is to be distinguished from the biblical [midrash] only by an external factor, canonization' (cf. Teugels 2004:199). Vermes uses 'midrash' and 'exegesis' as synonyms. He also points out that the public recitation of Scripture, as part of Temple worship, became the essential feature of the synagogue liturgy already in pre-Christian times. By the time of the New Testament, such public recitation had become a well-established custom (cf. Teugels 2004:201).

Midrash is a Hebrew term, which is mostly used outside rabbinic literature, usually in the Hebrew Bible and in Qumran studies. One should realise that, like most technical terms, the verb darash, from which the noun midrash is derived, has a common meaning, namely 'to seek' or 'to investigate' (cf. Bruns 1992:104). The verb ' $d r s h$ ' occurs frequently in the Hebrew Bible and Qumran literature. Renee Bloch (2001:30) concludes that the verb drsh indicates the focus of the study on the mighty interventions of God in the history of Israel. More generally, midrash can be taken to mean 'account', in the sense of giving an account of what is written. 'Giving an account' either means simply 'telling', or in a more complex sense 'accounting for', in which case the task is to address whatever becomes an issue when the Torah is studied or recited, or when an interpretation of the Torah is called for. In Jewish tradition, Gerald Bruns (1992:105) points out another point of view, namely, that midrash indicates a great range of possible applications.

In the Hebrew Bible, the noun 'midrash' occurs twice only in the book of Chronicles. ${ }^{6}$ However, Lieve M. Teugels (2004:153) points out that the meaning of the term, as it is used in Chronicles, is unclear and disputed among scholars. In such a context, midrash seems to refer to a 'book', possibly even to 'a book of interpretation'. If so, this usage of the term could well have been a precursor of, and even an inspiration for the technical use of 'midrash' by rabbis. The Chronicler used the term ' $m d r s h^{\prime}$ for historical works, which glossed Scripture for the purpose of instruction and edification. It is, however, a huge leap from the realisation of such use to the conclusion that midrash is ubiquitous throughout the Hebrew Bible.

Most often, however, the term is used in a religious sense. It means to frequent a cultic place, to seek God, or to seek the response of God in worship or in personal prayer (cf. Am 5:5; 2 Chr 1:5; Dt 12:5; Ps 34:5, 69:33, 105:4). This meaning was common in the post-exilic age.

3.Other pioneers and advocates of the importance of midrash for historical criticism of the Bible were the French scholars Andre Robert and Renee Bloch. See Lieve M. Teugels (2004:142)

4. The earliest relevant material appears in the Deuteronomic corpus. See Geza Vermes (1970:199). Other notable examples of alleged midrash in the Hebrew Bible 38, 119-188) 'Midrash': Palestine Jews and the Hebrew Bible in the Greco-Roman Period. See also Geza Vermes, Scripture and tradition in Judaism: Haggadic studies, esp. pp. 1-10: 'Introduction: Towards a new synthesis' and 'Bible an Midrash: Early Old Testament exegesis' in Post biblical Jewish studies, pp. 59-91.

5.See G. Porton (1985), 'Midrash': Palestinian Jews and the Hebrew Bible in the Greco-Roman Period, esp. pp. 106-108. Porton tends to hold a fairly broad view of midrash, which also includes non-rabbinic genres. See also his 'Rabbinic midrash' in the Anchor Bible Dictionary (1992:818-822. see also J. Neusner's (1987) section on 'Midrash in the Dead Sea Scrolls', in his What is midrash?).

\section{Midrash and exegesis}

Midrash is a genuine hermeneutical practice, in the sense that its purpose is to elucidate and understand the scriptural text. Craig A. Evans (1992) rightly pointed out the comprehensive exegetical range of midrash. The functions of midrash range from the pure explication and elucidation of the biblical text involved (exegesis), to the blatant 'reading in' of extraneous ideas. ${ }^{7}$ Philip Alexander confirmed such a range of meaning for exegesis in his study of midrash. The task of midrashic commentators can be seen as twofold - as both exegetical as well as eisegetical: it involves both drawing out the meaning which is implicit in Scripture, and reading meaning into Scripture (cf. Alexander 1984:7).

There is some evidence to suggest that the early Jewish commentators were not unaware of this distinction, though, in general, they gave the impression that they were merely drawing out the objective contents of Scripture. In practice, it is difficult to separate exegesis from eisegesis, since both processes often occur simultaneously in the same act of interpretation. The darshanim are adept at exploiting real problems in the text as a way of reading their own ideas into Scripture. In any given instance, it is probably impossible to say whether an interpretation was suggested simply by meditating on Scripture, or whether it was deliberately devised as a way of attaching certain ideas to Scripture.

Exegesis was required to adapt and complete Scripture, so that it might, on the one hand, be applied to the present time, and, on the other hand, satisfy the requirements of polemics. The resulting form of interpretation, which is not primarily concerned with the immediate meaning of the text, but rather with discovering principles for providing a non-scriptural problem with a scriptural solution, may be called 'applied' exegesis. Vermes further clarifies the features of applied exegesis, claiming that the point of departure for exegesis was no longer the Torah itself, but contemporary customs and beliefs, which the interpreter attempted to connect with Scripture, in an attempt to justify them (cf. Vermes 1970:221). The result was a closely reasoned corpus of systematic exegesis that eventually determined the whole orientation of individual and social life.

\section{Midrash and aggadah}

The Book of Ruth, as it is interpreted in Jewish tradition, is mainly aggadah, meaning that it is narrative in nature. The concept of aggadah originated from the concept of the Torah. The Torah stands on a dual foundation: both that of halakhah and aggadah. On the one hand, halakhah refers to those parts of the Torah that are legal in nature. It is found in the Pentateuch, or in the body of (originally) oral teachings contained in the Talmud and the Midrash. ${ }^{8}$ On the other hand, aggadah consists of those parts of the Torah, either written or oral, that are narrative in nature. 'Narrative', which is the closest synonym to aggadah, includes purported biography, theology, exhortation and folklore (cf. Heschel 2005:1; Neusner 2002:41). Haggadic teachings are not concerned with prescribing behaviour. In a given aggadah, contradictory sources can be presented together; there is no need to arrive at a decision or practice regarding them, so that even differing traditions are preserved.

Both Ruth Rabbah and the Targum to Ruth, dealing with exegetical traditions, are mainly midrashic aggadah. We therefore need to delineate and elaborate more on the relationship and connection between midrash and aggadah. There is common agreement that midrash and aggadah are closely related. Lieve Teugels (2004:151) confirms the close relationship that exists between the two, and claims that the interchanging of the terms 'aggadah' and 'midrash' was all but the rule in scholarship

7.It may be stated here for clarity's sake that 'rabbinic (and pre-rabbinic, inner-biblical) exegesis', which lacks the 'midrash form', share(s) this characteristic. 
until the last few decades of the past century. Most medieval Jewish scholars, such as Nachmanides (Ramban), used the terms 'midrash' and 'aggadah' interchangeably.'

However, Teugels (2004:151) admits that rabbinic scholars usually distinguish between the two terms. On the one hand, aggadah tends to be defined as those parts of rabbinic literature which are not 'halakah', denoting the narrative parts of traditional Jewish literature, whether or not explicitly referring to the Hebrew Scriptures. On the other hand, midrash means the rabbinic interpretation of the Hebrew Bible, irrespective of its legal or narrative content (cf. Stemberger 1996:238-239). Hence, aggadah is a term with a much broader connotation than midrash, with the former term referring to Jewish narrative material in general, without taking into consideration the literary form in which it appears.

\section{THE USE OF MIDRASH IN THE EXEGESIS OF THE BOOK OF RUTH}

\section{Gap-filling in the Bible and Midrash}

Biblical stories, like all other stories, tend to be narrated with 'gaps', not giving all the details of what happened between one event and another. Lieve Teugels (2004:42) discusses the role of the reader, demonstrating that readers are keen to fill in all kinds of details in the process of interpretation. Meir Sternberg (1996:186) also introduced the concept of 'gap filling' with regard to the active and interpretative stance that a reader takes when dealing with a biblical story.

Midrash is used to fill in the gaps in Jewish tradition. For example, a gap occurs in respect of time at the beginning of the Book of Ruth. The indication of time is neither specific nor defined in Ruth $1: 1$, which merely refers to the fact that it was 'in the days when the Judges judged'. Such lack of definition may be explained in terms of the approach taken by the rabbi concerned. Rabbis Nosson Scherma and Meir Zlotowitz assert that they believe that the precise year of the event described is unimportant. In addition, they state that the Scripture is not a historical book, and that the narratives that it contains are often incomplete and the chronology indefinite (cf. Scherman \& Zlotowitz 2004:xxi).

The author of Megillas Ruth, A.J. Rosenberg (2001:114), also echoed the same view. The period of the Judges began with the death of Joshua and lasted until the time of King Saul when he implemented a monarchy in Eretz Yisrael, which was a period of roughly 350 years. ${ }^{10}$ The gap in the narrative leaves open a wide range of possibilities. Rabbis Nosson Scherman and Meir Zlotowitz (2004:xx) express the belief that no sage can tell us when the story of Ruth took place. However, the interpreters of midrash fill in such a time gap. The Jewish rabbis indicate a network of stories, describing the period of the Judges. Rabbis Nosson Scherman and Meir Zlotowitz (2004:xx) point out that the network concerned is similar in many ways to two of the sorriest tales in the Scripture, which are found at the conclusion of The Book of Judges. The first is the narrative of the concubine in Giv'ah (Jdg 19), which tells the story of an atrocity which led to a civil war that resulted in more than 80000 deaths and the virtual decimation of the tribe of Benjamin. The second is the narrative of the idol of Micah that led astray a sizeable portion of

9.For example Nachmanides is supposed to have said: "We also have a third book which is called the Midrash, which means "Sermons". This is just as if the bishop were to stand up and make a sermon and one of his hearers liked it so much that he wrote it down. And as for this book, the Midrash, if anyone wants to believe in it, well and good, but if someone does not believe it, there is no harm ... Moreover we call Midrash a book of "Aggadah", which means razionamento, that is to say, merely things that a man relates to his fellow.' Cf. H. Maccoby (1982), 'The Vikuah of Nahmanides' in his Judaism on trial: Jewish-Christian disputations in the Middle Ages.

10.The rabbis estimated this period to have lasted from about $1400 \mathrm{BCE}$ to about $1100 \mathrm{BCE}$. It was the resultant chaos that brought famine to the land and exile to 1100 BCE. It was the resultant chaos that brought famine to the land and exile to
Elimelech. See Rabbi A.J. Rosenberg's The Midrashic Approach to twr The Book Elimelech. See the tribe of Dan (Jdg 18). These incidents are set in an indefinite timeframe, leading to commentators disagreeing about exactly when they occurred.

The two above-mentioned chaos-inducing events pretended to have occurred during the period of the Judges. They are normally used to illustrate the amount of social instability and political unrest prevailing during the period, with which the characters in the book had to cope. Referring to Ruth 1:1 ('and it came to pass'), the Midrash (cf. Rosenberg 2001:112) cites a tradition that every passage in the Bible beginning with the word wayehi tells of misfortune. The two-part word denotes sorrow: way ('woe') and $h i$ ('lamentation'). Rosenberg (2001:112) indicates that such words occur twice in the said verse, suggesting two misfortunes. According to the principle of 'no redundancy', every word is meaningful in the Scripture, which includes no superfluous words. Therefore, if a word or phrase appears to be redundant in context, the word or phrase in question must mean something that has not already been expressed (cf. Neusner \& Avery Peck 2005:296). The beginning of the Book of Ruth illustrates the instability of the social and political situation of the time described, which stresses the need for the coming of the messiah in fulfilment of the promise of God's plan for the Israelite community as the main purpose of the Jewish interpretation of the midrash.

\section{Application of the interpretation}

Midrash should be considered as a form of afterlife, rather than simply as a form of exegesis. Bruns (1992:105) points out that midrash is concerned with practice and action, as well as with the form and meaning of texts. Midrash is concerned with conveying the force of the text, as well as with addressing its problems of form and meaning. The sense of Torah is found in its application to life and in the conduct of those who live under its power. Such a principle of application applies both to homiletic aggadah, as well as to the explicitly legal constructions of halakhah.

Ruth's conversion is applied by the sages to the depiction of Ruth as the mother of a royal dynasty in the Israelite community. Ruth Rabbah to Ruth 1:16 declares that the principle of proselyte is written down in the Torah: 'When Naomi heard her say this, she began laying out for her the laws that govern proselytes' (cf. Neusner 1989:80).

Once again, the power and norm of Torah makes such a conversion possible. Ruth Rabbah also confirms the position of proselytes in the Torah, in respect of Ruth 1:18:

'And when Naomi saw that she was determined to go with her', said R. Judah b. R. Simon, "Notice how precious are proselytes before the Omnipresent. 'Once she had decided to convert, the Scripture treats her as equivalent to Naomi.'

The conversion of Ruth is confirmed by the interpretation of Ruth Rabbah in respect of Ruth 1:16 quotation '... and your God my God' remarking: 'this refers to the penalties and admonitions against sinning.'

The above quotation simply indicates that Ruth is obliged to commit herself to the divine law, meaning that she has to observe the Jewish religious regulations. Leila Leah Bronner shows that the effort that must be exerted in the interpretation relates to showing what constitutes a proper conversion in the Jewish tradition. In the interpretation of Jewish sages, the convert had to be sincere and determined, being willing both to accept the intense duties and the obligations of Jewish law (cf. Bronner 1993:152).

Furthermore, still another interpretation of 'for where you go, I will go' is presented. In the midrash interpretation of the story, Naomi begins the conversion ritual of Ruth by teaching her the importance of Sabbath observance. She tells Ruth that her people are prohibited from travelling beyond the set Sabbath boundaries on the day of rest. Ruth replies, 'Where you go, I will go.' Naomi 
then turns to sexual relations between men and women. Private meetings between men and women are forbidden. Ruth replies, 'Where you lodge, I will lodge.' Naomi tells her that the Jews have been commanded to observe $613^{11}$ commandments.

The emphasis on Ruth's conversion is based on the interest of the 'midrash-form' approach. The upholding of the position of Ruth in Israel's royal dynasty is deeply rooted in Jewish interpretation, because women were commonly regarded as inferior during the period concerned. As part of the royal line of the Davidic dynasty, Ruth, as a woman, needed legitimacy within the Israelite community. The Jewish commentators also make use of their exegetical methods to uphold the position of Ruth, a feminine Moabite, in an Israelite community. As a whole, Ruth's conversion reflects the Jewish interest of the community.

\section{It is homiletic}

Renee Bloch (2001:31) states that midrash is not a genre of the academy, but is, rather, a popular genre, and, above all, is homiletic. Its origin is certainly to be sought in the liturgical reading of the Torah during the Sabbath and feasts. The main task of midrashic interpreters is to teach the people of Israel moral behaviour, according to the requirements of the Torah.

Jewish commentaries may be used to fulfil the interpreter's purposes. Kirsten Nielsen (1997) points out that the most interesting aspect of the Midrash to Ruth, namely, Ruth Rabbah, is its characterisation of Ruth (cf. Nielsen 1997:18). Her character is described morally or negatively for the purpose of edification and upholding tradition. The departure of Elimelech, one of the characters of the Book of Ruth, from his country without a compelling reason was regarded as a grave sin. Moreover, Nielsen (1997:18) points out that his lack of solidarity with the poor was the reason for his premature death and his family's unfortunate situation. Elimelech's story exemplifies the principle of moral law of sin and punishment in Jewish law.

Ruth, in contrast, is beautifully drawn. Great emphasis is placed on her conversion, which fits in well with the use of the book during the Feast of Weeks. Neusner (1989:197) shows that one of the rabbinical interpretations that plays a decisive role in the understanding of the genesis and function of Ruth is concerned with king David's Moabite origins. The Davidic line and dynasty originated in Ruth's morality and hesed. The book was written to show how great is the reward for those who perform deeds of loving kindness (Ruth R. II, 14; cf. Levine 1973: Preface). Such an interpretation focuses on her commitment to Judaism and, in addition, emphasises her piety. Each generation of the Jewish community is required to follow her exemplary character through the homiletic function of midrash performed by the rabbis' teaching and their sermon, which is preached on every occasion of the Feast.

Philip Davies made a noteworthy point that scriptural explanation may be regarded as a historical lesson for the people of God (cf. Davies 1998:157). He believes that a large number of texts present figures from the past, who issue warnings about the behaviour of the nation of Israel, exhorting it to observe the will of God and to avoid catastrophe. Davies states that, while such compositions at times contain predictive elements and anticipate future events, their main function is usually exhortation. In other words, eschatological judgment and salvation are not the subjects of detailed prediction, but are, rather, prompts of ethical behaviour. Therefore, from the perspective of the communally contextualised exegesis and interpretation of the scriptural

11.Of the commandments, 606 are incumbent only upon Jews. An additional seven called by the sages 'the Noahide Laws' are incumbent upon all the descendants of Noah, i.e. all of humanity. Ruth's name indicates her acceptance of all these 613 the 613 comm com positive commandments correspond to the number of days during which the moon is seen. See Etan Levine (1973:59). text, ethical behaviour, as performed in accordance with the will of God, is aimed at in commentaries which are intended to propagate Jewish values and norms. In terms of Jewish exegesis, modelling is the main aim of interpretation. Moral teaching is an issue of critical importance, because Judaism is, at heart, a moral religion. The homiletic function of midrash became a useful means of achieving and perpetuating moral example down the generations in the history of Israel.

\section{Adaptation to the present}

Rabbinic methods of legal interpretation (halakah) and moral theological interpretation (haggada) correspond to mechanisms controlling every step of interpretation. Legal and theological hermeneutics may be considered as providing a model of the application of every principle of interpretation. Julio Trebolle Barrera (1998) believes that every interpretation is an application. The application of a legal rule to a particular case of halakah and the application of a moral message, whether written or oral, refers to the depiction of a new situation in the haggada (cf. Barrera 1998:497).

Howard Schwartz (1998) confirms that, in each generation, it has been the practice of Jewish people to return to the Scriptures for guidance in both ethical and spiritual matters (cf. Schwartz 1998:5). The radical changes in culture and environment that they experienced over the ages made it necessary to interpret the ethical laws in the Scriptures so that they would be applicable to their contemporary situation. Thus the Bible, and specifically the Torah, is not only the covenant between the people of Isaac and God,12 but it is also the source of the primary myths of the culture and the bedrock for all commentary, both in the halakhic, or legal, realm and in the aggadic, or legendary, realm. Indeed, it is not difficult to understand why all subsequent sacred texts exist in the shadow of the Holy Scriptures.

Lieve Teugels (2004:167) states that rabbinic exegesis is always theological. It actualises biblical texts and develops biblical notions which, by definition, in terms of the rabbinic view, are divinely inspired or about the divine. Moreover, the fact that the interpretation of the Bible was considered as Oral Torah involved a religious duty to engage in it. This combination of exegesis and theology, which surpasses the formal characteristics of the midrash (though it is embodied in them) is called a 'process of world-making' by Michael Fishbane (1998). That is, midrash is not just part of rabbinic culture, but helps to make the culture:

Consequently, the world of the text serves as the basis for the textualization of the world - and its meaning. Through exegesis new forms arise, and the content varies from one teacher to another. What remains constant is the attempt to textualize existence by having the ideals of (interpreted) Scripture embodied in everyday life. This process of world-making is the ultimate poesis of the exegetical imagination even as the conversion of the biblical text into life is the culmination of the principle of similarity.

(cf. Fishbane 1998:4)

The sages responded to the criteria of the position of Ruth, reaffirming her legitimacy. Ruth Rabbah, in reference to Ruth 1:4, states the following:

'These took Moabite wives':

It was taught on tannaite authority in the name of R. Meir, 'They did not convert them nor baptize them nor had the law been taught: "Amonite male", but not female, "Moabite male", but not female.' Since such a law had not been taught, permitting marriage to a formerly prohibited ethnic group, they did not escape punishment on that account.

The above quotation illustrates that women were not excluded. In Deuteronomy 23:4-7, the rabbis interpreted the abovementioned Pentateuch prohibition to mean that male Moabites

12. On Shavuoth, many Sephardic communities read a ketubah (Jewish wedding contract) referring to the marriage of God and Israel, which was written by Israel Najara during the 16th century in Safed. See Howard Schwartz (1998:87) for partial translation of the text. 
were forbidden to come into the congregation of the Lord. They based this interpretation on the use of the male singular form in the biblical text. Leila Leah Bronner (1993:146) concludes that the exegetical principle of 'a Moabite, but not a Moabitess' allowed Ruth to be accepted. Once again, we can understand the exegetical motive behind the interpretation.

The position of Ruth in the royal Davidic dynasty is always questioned, because of her foreignness, as she had been a Moabitess. The criticism of her position has led to quarrels and conflicts among the different Jewish groups through the ages. Despite such questioning, midrashic interpretation affirmed the position of Ruth in the Israelite community. Ruth Rabbah 1:14, which discusses the act of kissing, illustrates the royal linkage of Ruth:

\section{'... and Orpah kissed her mother-in-law':}

Every act of kissing is frivolous except for three:

the kiss of a high position, the kiss of meeting, and the kiss of departing.

The kiss of a high position: 'Then Samuel took the vial of oil and poured it on his head and kissed him' (1 Sam. 10:1).

The kiss of meeting: 'And he met him in the mountain of God and kissed him' (Ex. 4:27).

And the kiss of departing: 'and Orpah kissed her mother-in-law.' R. Tanhuma said, 'Also the kiss of kinship: "And Jacob kissed Rachel" (Gen. 29:11).

Why so? Because she was related to him.'

Ruth Rabbah tries to include Ruth in the royal dynasty. Andre LaCocque held the same view actively describing her position in the Jewish royal community. Ruth was not just a passive instrument for the preservation of the ancestral line of David. Andre LaCocque (1990:89) states that '[s] we was a beacon of loyalty for Israel, a woman to rank with the matriarchs of the nation'. Ruth is understood as being a link to David, because David is given the highest priority in the Israel community.

Scholars proclaim that what the proselyte, therefore, accomplishes is to take shelter under God's wings, thereby standing in the royal line of David, Solomon, and the Messiah. Jacob Neusner (2004) observes that the point is repeatedly made that Ruth the Moabitess, who is perceived by the ignorant as an outsider, enjoyed complete equality with all other Israelites, because she had accepted the yoke of the Torah, married a great sage, and, through her descendants, produced the messiah sage, David (cf. Neusner 2004:198-199, 2005:107).

Faced with the exemplary character of this foreign woman, who will also become the ancestress of the Davidic line, the rabbis of the Talmud felt that they had to legitimise Ruth's conversion by means of halakah. Having accomplished her acceptance into the fold, they wished to underscore her merit and her extraordinary kindness and valour. Leila Leah Bronner (1993:146) expresses the belief that their doing so made her a suitable figure to stand at the beginning of the Davidic or later messianic line.

Leila Bronner (1993:80) praises Ruth's legitimate position in the Israelite community, claiming that it is in marriage and motherhood that Ruth fulfils her role. By her dedication to the Torah, as well as to the feminine functions and values respected and venerated by the sages, she won their approval and esteem. They compare her to the matriarchs who built the house of Israel, whose merit also derives almost entirely from their fulfilment of the maternal role. The sages accord great respect to the exemplary women of the Bible more than towards any actual women of whom they knew. We may conclude that the adaptation of their writings to the present situation is motivated by 'midrash-form' purpose.

\section{CONCLUSION}

Midrash is an approach of early Jewish exegesis, which was used to interpret the Scripture of the Jewish people for teaching and preaching. This approach represents a specific type of exegetical method, which was used in antiquity. The sages used this approach to uphold their tradition, norms and values, in the face of their surrounding political, historical and cultural challenges and background.

\section{REFERENCES}

Alexander, P.C., 1984, 'The rabbinic hermeneutical rules and the problem of the definition of midrash', Proceedings of the Irish Biblical Association 8, 97-125.

Barrera, J.T., 1998, The Jewish Bible and the Christian Bible: An introduction to the history of the Bible, Brill Academic Publishers, Grand Rapids.

Bloch, R., 2001, 'Midrash', in W.S. Green (ed.), Approaches to Ancient Judaism: Theory and practice, pp. 30-33, Scholars Press, Missoula, MT.

Bronner, L.L., 1993, 'A thematic approach to Ruth in rabbinic literature', in A. Brenner (ed.), A feminist companion to Ruth, Feminist Companion to the Bible 3, pp. 146-69, Sheffield Academic Press, Sheffield.

Bronner, L.L., 1994, From Eve to Esther, Rabbinic reconstructions of Biblical women, Gender and the Biblical tradition, Westminster John Knox press, Louisville.

Bruns, G.L., 1992, Hermeneutics ancient and modern, Yale University Press, New Haven, CT.

Davies, P.R., 1998, Behind the Essenes: History and ideology in the Dead Sea Scrolls, Scholars Press, Atlanta.

Evans, C.A., 1992, Non-canonical writings and New Testament interpretation, Hendrickson Publishers, Peabody, MA.

Fishbane, M., 1998, The Exegetical imagination on Jewish thought and theology, Harvard University Press, Cambridge, MA.

Fraade, S.D., 1991, From tradition to commentary: Torah and its interpretation in the Midrash Sifre to Deuteronomy, State University of New York Press, Albany, NY.

Halivni, D.H., 1986, Midrash, Mishnah, and Gemara: the Jewish predilection for justified law, Harvard University Press, Cambridge, MA.

Halivni, D.H., 1991, Peshat and Darash: Plain and applied meaning in rabbinic exegesis, Oxford, New York.

Heschel, A.J., 2005, 'Introduction', in G. Tucker (ed.), Heavenly Torah: As refracted through the generations, pp. ii-3, Continuum, New York.

LaCocque, A., 1990, The feminine unconventional: Four subversive figures in Israel's tradition, Minneapolis, Augsburg Fortress, MI

Maccoby, H., 1982, Judaism on trial: Jewish-Christian disputations in the Middle Ages, Fairleigh Dickinson University Press, London.

Levine, E., 1973, The Aramaic version of Ruth, Biblical Institute Press, Rome.

Neusner, J., 1987, What is Midrash?, Guides to Biblical Scholarship: New Testament Guides, Fortress Press, Philadelphia.

Neusner, J., 1989, Ruth Rabbah: An analytical translation, Scholars Press, Atlanta, GA.

Neusner, J., 1992, 'Rabbinic midrash' in D.N. Freedman, G.A. Herion, A.B. Becket et al. (eds.), The Anchor Bible Dictionary, pp. 818-822, Doubleday, New York,

Neusner, J., 2002, Rabbinic Judaism: The theological system, Brill Academic Publishers, Boston.

Neusner, J., 2004, The emergence of Judaism, Westminster John Knox press, Louisville.

Neusner, J., 2005, Rabbinic literature: An essential guide, Abingdon Press, Nashville, TN.

Neusner, J. \& Avery Peck, A.J., 2005, Encyclopedia of Midrash: Biblical interpretation in formative Judaism, vol. 1, Brill, Leiden.

Nielsen, K., 1997, The Old Testament library: Ruth, Knox Press, Leiden.

Porton, G.G., 1979, 'Midrash: Palestinian Jews and the Hebrew Bible in the Greco-Roman Period', Aufstieg und Niedergang der Römischen Welt (Rise and Fall of the Roman World - book series) II.19.2, 103-138. 
Porton, G.G., 1985, 'Rabbinic midrash', in J. Neusner (ed.), Judaism in Late Antiquity, vol. 1, pp. 217-238, A.R. Allenson, Naperville.

Rosenberg, A.J., 2001, The midrashic approach to twr in the Book of Ruth, Fortress Press, Minneapolis, MI

Scherman, N. \& Zlotowitz, M., 2004, A New Translation with a commentary anthologized from Talmudic, midrashic and rabbinic sources, Mesorah Publications, New York.

Schwartz, H., 1998, Re-imagining the Bible: The storytelling of the rabbis, Oxford University Press, New York.

Stemberger, G. \& Bockmuehl, M.N.A., 1996, Introduction to the Talmud and Midrash, T\&T Clark, Edinburgh.

Sternberg, M., 1996, The poetics of biblical narrative, Oxford University Press, London.
Talmon, S., 2002, “"The crystallization of the canon of Hebrew Scriptures" in the light of biblical scrolls from Qumran', in E.D. Herbert \& E. Tov (eds.), The book as book: The Hebrew Bible and the Judaean desert discoveries, pp. 182-192, The British Library, London.

Teugels, L.M., 2004, Bible and midrash: The story of 'The Wooing of Rebekah' (Gen. 24), Peeters, Leuven.

Van der Heide, A., 1997, 'Midrash and exegesis', in J. Frishman \& L. Van Rompay (eds.), The book of Genesis in Jewish and oriental Christian interpretation, pp. 47-58, Peeters, Leuven.

Vermes, G., 1970, 'Bible and midrash: Early Old Testament exegesis', in P.R. Ackroyd \& C.F. Evans (eds.), The Cambridge history of the Bible, pp. 199-231, Cambridge University Press, London. 